\title{
STUDIES ON SOME PHENOLIC AND FLAVONOID COMPOUNDS OF RED SORGHUM BRAN AND THEIR ANTIBACTERIAL ACTIVITY
}

\author{
(Received:1.7.2007) \\ By \\ S. M. Morsy , M. S. Halaby* and R.N. Sandak \\ Department of Crops Technology, Food Technology Research Institute, Agricultureal Research Center, \\ Giza ,Egypt. *Department of Nutrition \& Food Science, Faculty of Home Economics, Helwan \\ University, Cairo, Egypt.
}

\begin{abstract}
Flavonoid and phenolic compounds of red sorghum bran were investigated through ethanolic $70 \%$ extraction and subsequent extraction by diethyl ether and ethyl acetate. The diethyl ether extract contained three aglycons, i.e identified kaempferol, quercetin and apigenin. The ethyl acetate extract proved to contain luteolin, astragtein (Kaempferol-3-glucoside), rhoifolin (Apigenin-7-rutinoside), gallic acid and ellagic acid. The residual material after solvent fractionation contained vicenin II (Apigenin-6-8di-C-glucoside). All isolated and purified compounds were identified using both physical and chemical methods and were further confirmed by the spectral measurements (U.V. Spectrum and H-NMR spectra). The antibacterial effects of the compounds and extracts were studied by using the agar diffusion technique on four gram positive bacteria namely Staphylococcus oureus, Sarcina lutea, Bacillus pumilus and Bacillus subtilis and two gram negative bacteria Escherichia coli and Broodetella brochiseptica.
\end{abstract}

Key words: antioxidants, antibacterial effects, bran, flavonoid, phenolic compounds, red sorghum.

\section{INTRODUCTION}

Sorghum bicolor is the fifth most important cereal crop after wheat, rice, maize and barley in terms of production (FAO, 2005). The total world annual sorghum production is over 60 million tons from a cultivated area of 46 millions ha. Moreover, some red sorghum varieties have higher antioxidant activities than the most important sources of natural antioxidants. Oxidation products of peroxidase and polyphenol oxidase (benzoquinones and polymeric compounds) affect food quality (Dicko et al., 2006).

Phenolic compounds are commonly found in both edible and non-edible plants and they have been reported to have multiple biological effects including antioxidant activity. Crude extracts of vegetables, herbs, fruits, cereals and other plant materials rich in phenolics are increasingly of interest in the food industry because they retard oxidative degradation of lipids and thereby improve the quality and nutritional value of food. The importance of the antioxidant constituents of plant materials in the maintenance of health and protection from coronary heart disease and cancer is also raising interest among scientists and food manufactures. In fact, consumer as the trend of the future is moving towards functional food with specific health effects (Kahkonen et al., 1999 and Sandak and El-Hadidy 2004).

Phenolic sorghum phytochemicals are important for human nutrition (Awika et al., 2004). Phenolic compounds are the most widely distributed secondary metabolites, ubiquitously present in the plant kingdom. Among cereals sorghum had the highest content of phenolic compounds reaching up to $6 \%(\mathrm{~W} / \mathrm{W})$ in some varieties (Awika and Roony, 2004 and Dicko et al., 2005). While, the amount of phenolic compounds which present in all sorghums influence, its genotypes and environmental conditions. The main classes of phenolic compounds are simple phenols hydroxybenzoic acids, hydroxycinnamic acids, flavonoids (flavanols, flavones, flavanones, isoflavones and anthocyanins), chalcones, lignain, hydroxycoumarins and polyflavans (Chung et al., 1998 and Krueger et al., 2003).

These compounds are soluble in water or organic solvents. Sorghum does not contain tannic acid and hydrolysable tannins (Waniska, 2000 and Awika et al., 2004). Phenolics play an important role in plant metabolism, but also, protect the plant against stresses. For instance, it has been recently shown that flavonoids, such as catechin, regulate the auxin transport in plants and 
therefore, play an important role in plant development (Brown et al., 2001).

Flavonoids constitute the largest class of phenolic compounds with more than 3000 structures, possessing in common a flavylium unit $\left(\mathrm{C}_{6}-\mathrm{C}_{3}-\mathrm{C}_{6}\right)$ (Lacobucci and Sweeny, 1983). Sorghum contains flavonoids such as flavanols (flavan-3-ols and flavan-4-ols), flavanones, flavones and anthocyanins (Haslam, 1998 and Awika and Ronny, 2004). The flavan-4-ols apiforol (pro-apigeninidin or leuco-apigeninidin) and tuteoforol (proluteolinidin or leucoluteolinidin) are abundant in sorghum and precursors of apigeninidin and luteolinidin, respectively (Ferreira and Slade, 2002, and Hagerman, 2005).

Flavonoids are widely distributed in the plant kingdom. They are mainly produced as a pigment of many shades, and play an important rule in normal growth, development, and defense of plants. At the biochemical level, flavonoids act as enzyme inhibitors, provide defense against ultraviolet radiation, act as chelating agents for metals, and as reducing agents (Harris, 1992 and Rice-Evans et al., 1995). Flavonoids have been reported to exhibit a wide range of biological effects, such as antibacterial, antiviral, antiinflammatory, anti-allergic and anticancer. They are known to inhibit lipid peroxidation and platelet aggregation and to affect capillary permeability and fragility. (Chu et al., 2000 and Knekt et al., 2002).

Mechanisms by which flavonoids have been proposed to provide health benefits in addition to being direct chemical protectants and involve modulator effects on a variety of metabolic and signaling enzymes. Flavonoids have been shown to block the angiotensin-converting enzyme that raises blood pressure; they inhibit cyclooxygenase, which forms prostaglandin and they block enzyme that produce estrogen. The implications of these in vitro inhibitory actions are that certain flavonoids could prevent platelet aggregation, reducing heart disease and thrombosis also, inhibit estrogen synthesis, which binds estrogen to receptors in several tissues, thus decreasing the risk of estrogen-related cancers (Dillard and German, 2000). Phenolic acids in sorghum are found in free or bound as esters, and are concentrated in the outer layers of the grain (Waniska, 2000; Awika et al., 2004 and Dicko et al., 2006).

Sorghum with black pericarp or purple/red plants has higher levels of phenolic compounds (flavan-4-ols and anthocyanins) than the other varieties (Dykes et al., 2005). The biological activities of flavonoids are actions against free radicals, free radical mediated cellular signaling, inflammation, allergies, platelet aggregation, microbes, ulcers, viruses and tumors and hepatotoxins (Kinsella et al., 1993).

The retardation of autoxidation is therefore a key to product quality, because most consumers prefer natural food additives to synthetic ones. Natural antioxidants are of increasing importance (Krings and Berger, 2001; and Negi and Jayaprakasha, 2003). Although significant advances have been made in food preservation, spoilage and pathogenic bacterial growth during food preparation, storage and distribution remain a serious problem. Most approaches to food preservations employ physical and/or chemical methods that reduce pre-and post-treatment bacterial contamination of foods, and include additives, packaging or storage conditions that retard or inhibit the growth of borne bacterial pathogens, and/or reduce processing requirements for their elimination in foods are desired (Bowles and Jay 1993; and Leuschner and Ielsch 2003).

Antioxidants are major ingredients, play an important role in manufacturing, packaging and storage of lipid containing foods. Synthetic antioxidants are usually used in food industry to reduce deterioration and rancidity of oils and fats. There has been growing concern regarding the possible activity of such synthetic antioxidants to cause liver damage. Therefore development of safer, inexpensive natural antioxidants is essentially (Yen and Due, 1993).

Furthermore, most consumers prefer natural food additives to synthetic ones;since natural antioxidants are of increasing importance. Recent work is beginning to shed light on the relation of flavonoids and other dietary phenolic constituents to these protective effects.

This investigation aimed to isolate and identify flavonoid and phenolic compounds of red sorghum bran as a waste and of a low cost. In addition the effect of the extracted flavonoid and phenolic compounds on six different bacteria strains was tested.

\section{MATERIALS AND METHODS 2.1 Materials}

Red sorghum (Sorghum bicolor L.) cultivar Assiut 14 was obtained from Agricultural Research Center, Giza - Egypt. Sorghum grains were finely ground then passed through 40-mesh sieve to separate the bran. Authentic phenol and flavonoids compounds were purchased from Sigma Co. and Deisenhofen, Germany.

\subsection{Methods}

\subsubsection{Extraction, isolation and purification}



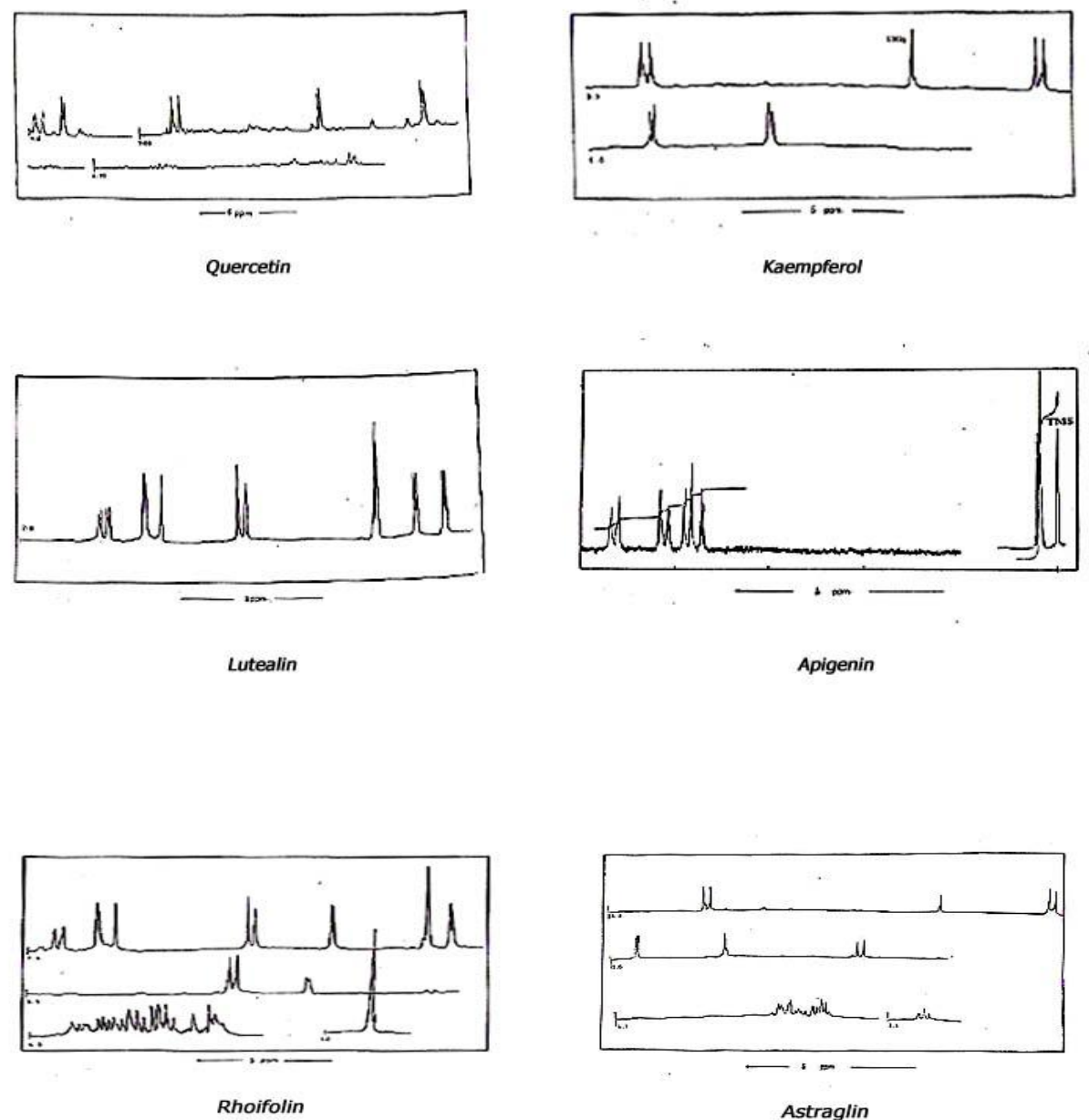

Astraglin
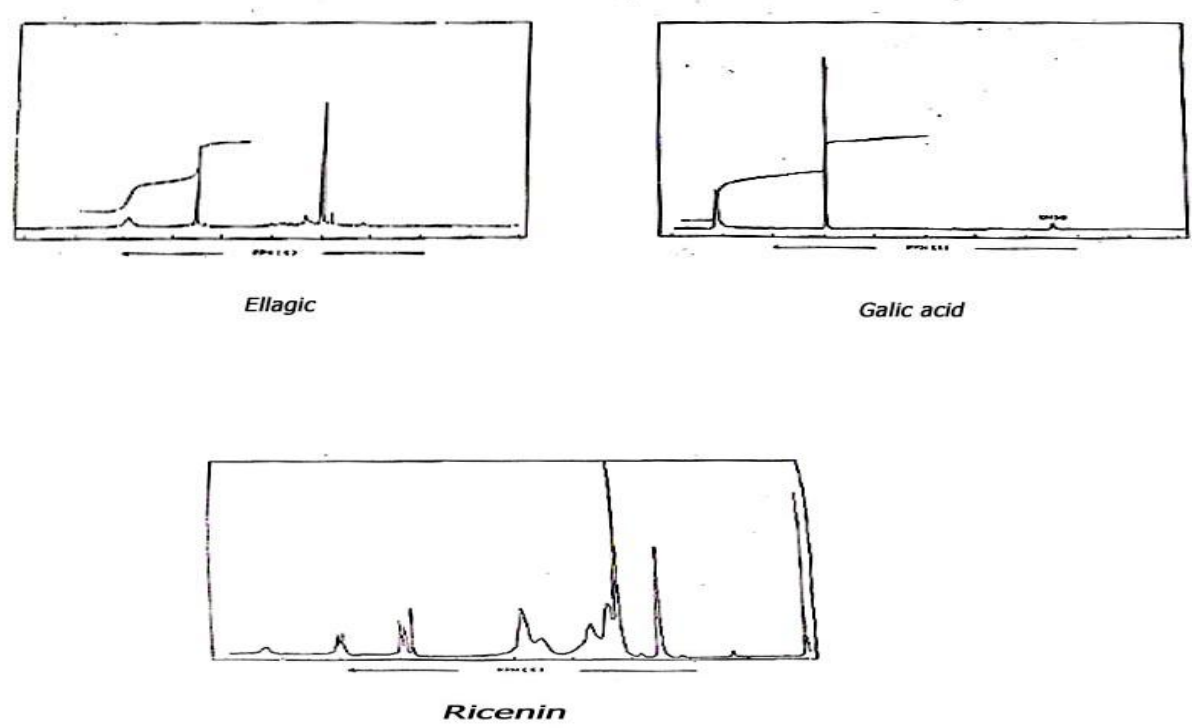

Fig. (1): ${ }^{1} \mathrm{H}$-NMR Spectroscopy of flavonoid and phenolic compounds from red sorghum bran extracts. 
Air-dried bran $(500 \mathrm{~g})$ was finely powdered and extracted with petroleum ether $\left(40-60^{\circ} \mathrm{C}\right)$ to remove fats and resinous materials. The residue was exhaustively extracted with 2 liters $70 \%$ ethanol by heating on a boiling water bath for 6 hours. Extraction was repeated until a color extract then the extracts were combined and concentrated to obtain aqueous ethanolic extract. The aqueous ethanolic extract was subjected to fractional extraction using diethyl ether followed by ethyl acetate according to Mabry et al. (1970).

Two-dimensional paper chromatography of diethyl ether, ethyl acetate extracts and the aqueous solution of the residual material using the solvent system butanol: acetic acid: water (4:1:5) and acetic acid $15 \%$ were performed, respectively, revealed the presence of many compounds of flavonoid and phenolic nature.

The compounds were detected under U.V. light and the major compounds were eluted with $70 \%$ ethyl alcohol. Each of the isolated compounds and authentic samples phenolic and flavonoid were subjected to one-dimensional Watman 3MM papers chromatographic technique using two different solvents (acetic acid 15\% and butanol: acetic acid: water, 4:1:5) for elution. The different spots (major flavonoid and phenolic compounds and authentic samples) were located by color reaction and $R_{f}$ values under U.V. lights with and without the presence of $\mathrm{NH}_{3}$ fumes according to Markham and Mabry (1968). These compounds were further purified over Sephadex LH 20 column prior to physical and chemical analysis.

\subsubsection{Physico-chemical analysis}

Complete acid hydrolysis was carried out by Hcl 2N (Geissman, 1962). The controlled acid hydrolysis by HCL $0.1 \mathrm{~N}$ (Seshadry, 1962) of the flavonoid glycosides under investigation yielded the sugar residues and the aglycones. Each compound was separately dissolved in pure methanol and examined for U.V. Spectrum (Shimadiu U.V. Visible. Recording Spectrophotometer Model, U.V.240) in the presence of diagnostic reagents according to Mabry et al. (1970).

${ }^{1} \mathrm{H}-\mathrm{NMR}$ apparatus examined all flavonoid and phenolic compounds separated from red sorghum bran. The ${ }^{1} \mathrm{H}-\mathrm{NMR}$ spectra of the trimethylsilyl ethers of all compounds were recorded in CDCL3 at $90 \mathrm{MHZ}$ and reported at $\delta$ values (ppm) relative to TMS as an internal standard on a Bruker WM90 apparatus.

\subsubsection{Antimicrobial activity of the flavonoid and phenolic extracts}

The antibacterial effect of the extracts and some of the isolated compounds was studied using the nutrient agar (peptone $0.5 \%$, beef extract $0.3 \%$, Difco agar $1.5 \%$ and $\mathrm{pH} 7.0$ ) according to A.P.H.A. (1971) on six different bacteria strains. Two gram- negative bacteria namely Escherichia coli and Broodetella brochiseptica, and four gram- positive bacteria namely Bacillus pumilus, Bacillus subtilis, Staphylococcus oureus and Sarcina lutea. The antibacterial activity was determined by the paper disc plate method described by Jacobes and Gerstin (1960). Whatman 3MM filter paper discs of $0.6 \mathrm{~mm}$ diameter were placed in petri dishes at the rate of one disc/ plate. Each powder extracts were dissolved in $0.7 \mathrm{ml}$ absolute ethanol to give 100 ppm of the crude compound. Each filter paper disc was moistened with exactly $0.2 \mathrm{ml}$ of tested solvent extract in two concentrations. The plates were incubated at $37^{\circ} \mathrm{C}$ for $24 \mathrm{~h}$. and the antibacterial activity was measured as growth zone of inhibition of microorganisms. All tests were run in triplicate for each sample and the mean of inhibition zones were given to asses the activity.

\section{RESULTS AND DISCUSSION}

\subsection{Isolation and purification of flavonoids from sorghum bran}

The present study deals with the polyphenolic compounds of red sorghum bran. Whereby, three flavonoid glycosides, four flavonoid aglycons and two phenolic acids were isolated from $70 \%$ ethanolic extract. From the diethyl ether extract three flavonoid compounds were isolated using preparative paper chromatography elution in $15 \%$ acetic acid and identified as kaempferol, quercetin and apigenine. Whilst, luteolin, astraglain (kaempferol-3-glucoside), rhoifolin (apigenin-7rutinoside), gallic acid and ellagic acid were isolated from ethyl acetate extract by preparative paper chromatography using water for elution.

The residual material after solvent fraction was dissolved in water and subjected to preparative paper chromatography using butanol: acetic acid: water (4:1:5) as the solvent system for elution which revealed the presence of one flavonoid glycosides namely vicenin II (apigenin6-8-di-C-glucoside). The structure of the isolated compounds was identified by physico-chemical analysis. Color reaction and $\mathrm{R}_{\mathrm{f}}$ values data are outlined in Table (1). 
Table (1): $\mathbf{R}_{\mathrm{f}}$ values and color reaction of the compounds isolated from red sorghum bran.

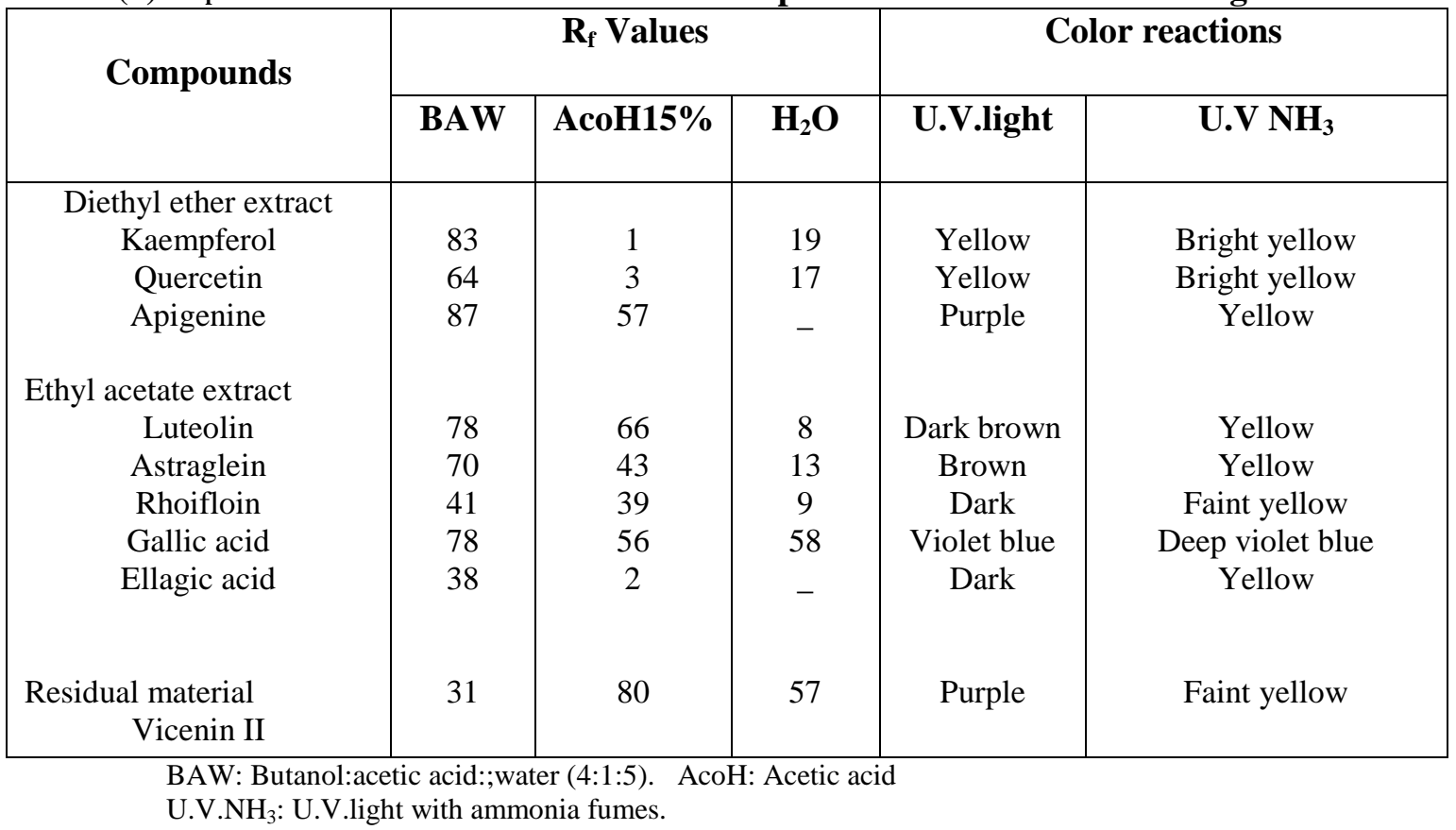

Table (2): U.V. spectral data ( $\lambda$ max. nm) of the compounds isolated from red sorghum bran extracts.

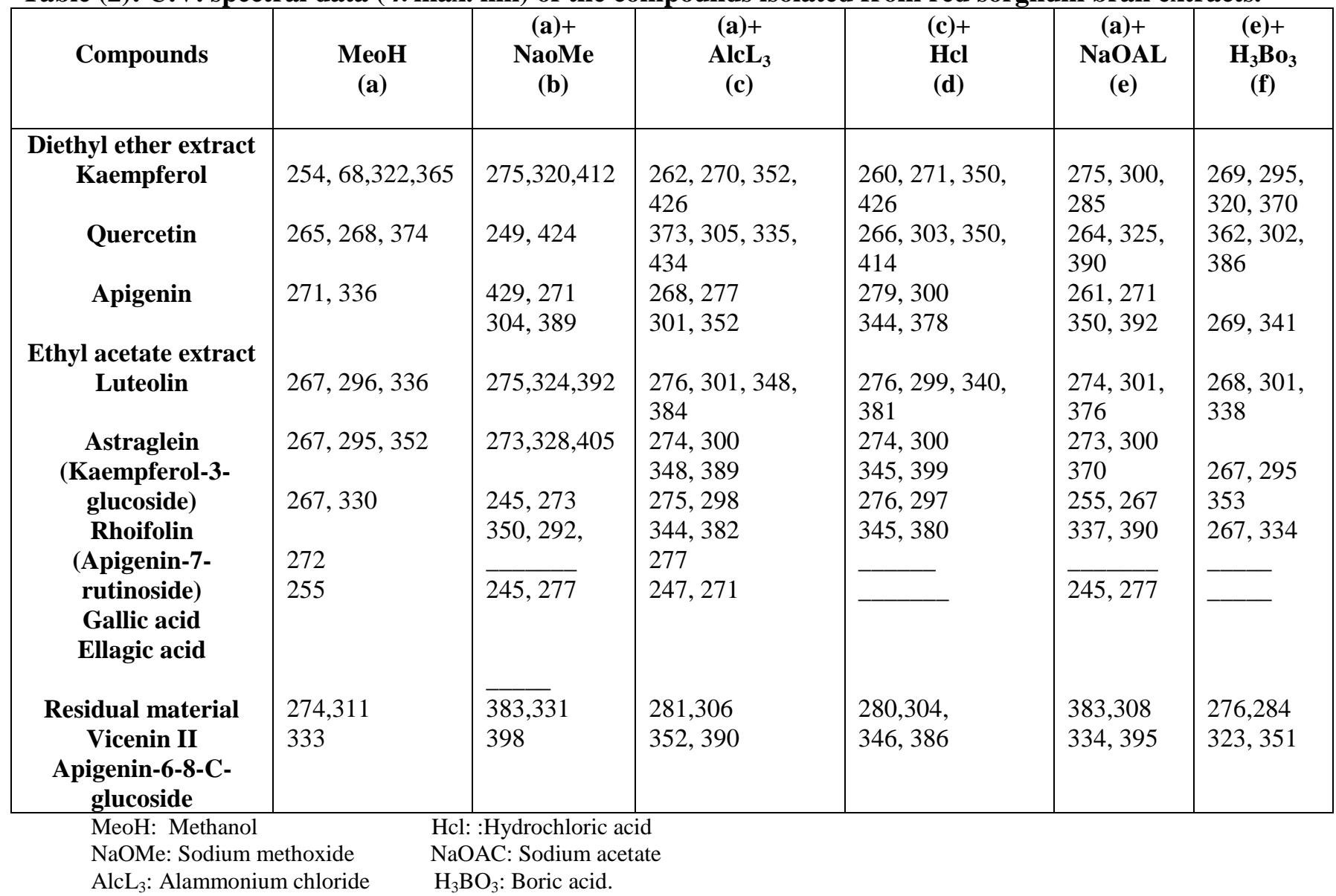


Table (3): ${ }^{1}$ HNMR data of the isolated compounds from red sorghum bran extracts.

\begin{tabular}{|c|c|}
\hline Compounds & Aglycon and sugar moicty $\delta(\mathrm{ppm})$ \\
\hline $\begin{array}{l}\text { Diethyl ether } \\
\text { extract } \\
\text { Kaempferol }\end{array}$ & $\begin{array}{l}\text { 7.88(d,j=8Hz,H-2 and H-6 }), 6.77\left(\mathrm{~d}, \mathrm{j}=8.5 \mathrm{~Hz}, \mathrm{H}-3^{`} \text { and } \mathrm{H}-5^{`}\right) 0,6.41(\mathrm{~d}, \mathrm{j}=2.5 \mathrm{~Hz}, \mathrm{H}- \\
8), 6.12(\mathrm{~d}, \mathrm{j}=2.5 \mathrm{~Hz}, \mathrm{H}-6) \text {. }\end{array}$ \\
\hline Quercetin & $\begin{array}{l}7.64(9 \mathrm{dd}, \mathrm{j}=2.5 \mathrm{~Hz} \text { and } \mathrm{j}=8.5 \mathrm{~Hz}, \mathrm{H}-6), 7.56\left(\mathrm{~d}, \mathrm{j}=2 \mathrm{~Hz}, \mathrm{H}-2^{`}\right), 6.84(\mathrm{~d}, \mathrm{j}=8.5 \mathrm{~Hz}, \mathrm{H}- \\
\left.5^{\prime}\right), 6.3(\mathrm{~d}, \mathrm{j}=2 \mathrm{~Hz}, \mathrm{H}-8), 6.2(\mathrm{~d}, \mathrm{j}=2.5 \mathrm{~Hz}, \mathrm{H}-6)\end{array}$ \\
\hline Apigenin & $\begin{array}{l}\text { 7.41(dd,j =2.5Hz and } \mathrm{j}=9 \mathrm{~Hz}, \mathrm{H}-6), 7.3\left(\mathrm{~d}, \mathrm{j}=2 \mathrm{~Hz}, \mathrm{Hh}-2^{\prime}\right) 6.9\left(\mathrm{~d}, \mathrm{j}=8 \mathrm{~Hz}, \mathrm{H}-5^{\prime}\right), 6.78(9 \mathrm{~d}, \mathrm{j}=2.5 \mathrm{~Hz}, \mathrm{H}- \\
8) 0,6.43(\mathrm{~S}, \mathrm{H}-3), 6.42(\mathrm{~d}, \mathrm{j}=2.5 \mathrm{~Hz}, \mathrm{H}-6) \text {. }\end{array}$ \\
\hline $\begin{array}{l}\text { Ethyl acetate } \\
\text { extract } \\
\text { Luteolin }\end{array}$ & $\begin{array}{l}6.3(\mathrm{~d}, \mathrm{j}=2.5 \mathrm{~Hz}, \mathrm{H}-6), 6.44(\mathrm{~d}, \mathrm{j}=2.5 \mathrm{~Hz}, \mathrm{H}-8), 6.55(\mathrm{~S}, \mathrm{H}-3), 6.93(\mathrm{~d}, \mathrm{j}=8 \mathrm{~Hz}, \mathrm{H}- \\
\left.5^{\prime}\right), 7.35\left(\mathrm{~d}, \mathrm{j}=2 \mathrm{~Hz}, \mathrm{H}-2^{\prime}\right), 7.44\left(\mathrm{dd}, \mathrm{j}=2.5 \mathrm{~Hz} \text { and } \mathrm{j}=9 \mathrm{~Hz}, \mathrm{H}-6^{\prime}\right)\end{array}$ \\
\hline $\begin{array}{l}\text { Astragalin } \\
\text { (Kaempferol-3- } \\
\text { glucoside) }\end{array}$ & $\begin{array}{l}7.98\left(\mathrm{~d}, \mathrm{j}=8 \mathrm{~Hz}, \mathrm{H}-2^{`} \text { and } \mathrm{H}-6^{`}\right), 6.87\left(\mathrm{~d}, \mathrm{j}=8.5 \mathrm{~Hz}, \mathrm{H}-3^{`} \text { and } \mathrm{H}-5^{`}\right) \text {, } \\
6.23(\mathrm{~d}, \mathrm{j}=2.5 \mathrm{~Hz}, \mathrm{H}-8), 6.23(\mathrm{~d}, \mathrm{j}=2.5 \mathrm{~Hz}, \mathrm{H}-6) . \\
\left.\text { Sugar moiety:5.8(d,j=7.5Hz,H-1 }{ }^{\prime \prime}\right) 3.0-3.98(\mathrm{~m} \text { of the six glucose protons). }\end{array}$ \\
\hline $\begin{array}{l}\text { Rhoifolin } \\
\text { Apigenin-7- } \\
\text { rutinoside }\end{array}$ & 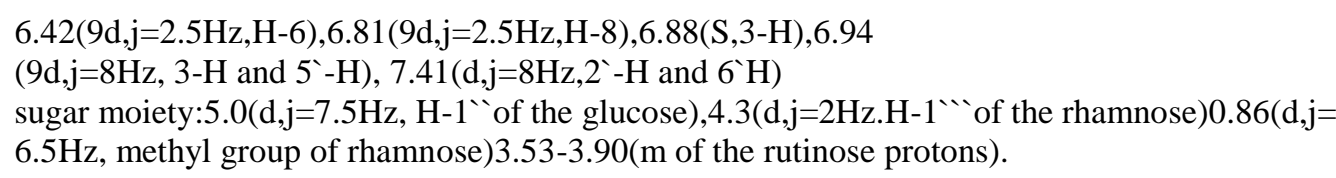 \\
\hline $\begin{array}{l}\text { Gallic acid } \\
\text { Ellagic acid } \\
\text { Residual } \\
\text { material } \\
\text { Vicenin II }\end{array}$ & 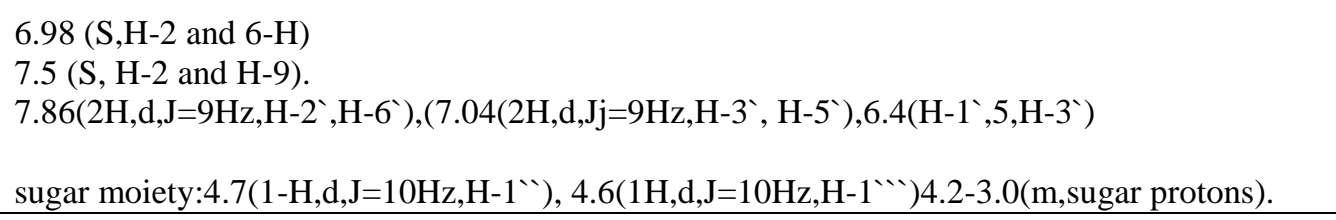 \\
\hline
\end{tabular}

Table (4): Anti-bacterial effects on flavonois and phenolic compounds.

\begin{tabular}{|c|c|c|c|c|c|c|}
\hline \multirow[t]{2}{*}{ Compounds } & \multicolumn{2}{|c|}{$\begin{array}{c}\text { Gram-negative } \\
\text { bacteria }\end{array}$} & \multicolumn{4}{|c|}{ Gram-positive bacteria } \\
\hline & Es. & Br. & St. & Sa. & Ba.p. & Ba.s. \\
\hline $\begin{array}{l}\text { Diethyl ethyl extract } \\
\text { Ethyl acetate extract } \\
\text { Residual material } \\
\text { Kaempferol } \\
\text { Quercetin } \\
\text { Apigenin } \\
\text { Luteolin } \\
\text { Astraglein } \\
\text { Rhoifloin } \\
\text { Gallic acid } \\
\text { Ellagic acid } \\
\text { Vicenin II }\end{array}$ & $\begin{array}{l}++ \\
++ \\
+++ \\
++++ \\
++ \\
++ \\
++ \\
+ \\
+ \\
++++ \\
+++ \\
++\end{array}$ & $\begin{array}{l}- \\
++ \\
++ \\
++++ \\
++ \\
+ \\
++ \\
+ \\
+ \\
+++ \\
++ \\
+\end{array}$ & $\begin{array}{l}+ \\
+++ \\
+ \\
+++ \\
++ \\
+++ \\
++ \\
+ \\
+ \\
+++ \\
+ \\
++\end{array}$ & $\begin{array}{l}++ \\
+++ \\
++ \\
++++ \\
+ \\
++ \\
+ \\
- \\
- \\
++++ \\
+++ \\
++\end{array}$ & $\begin{array}{l}+ \\
+++ \\
++ \\
+++ \\
++ \\
+ \\
++ \\
++ \\
+ \\
++++ \\
+++ \\
+\end{array}$ & $\begin{array}{l}+ \\
++ \\
++ \\
++++ \\
++ \\
++ \\
+ \\
+ \\
++ \\
+++ \\
++ \\
+++\end{array}$ \\
\hline
\end{tabular}

Bacteria:

Zone of inhibition (mm):

Es: Escherechia Coli = (+) from 11-13 mm.

Br: Brodetella broshiseptica $=(++)$ from $14-16 \mathrm{~mm}$.

St: Staphylococcus aureus $=(+++)$ from 17-19.mm.
Sa: Sarcina lutea $=(++++)$ from $20-24 \mathrm{~mm}$

Bap: Bacillus pumilus.

BaS: Bacillus subtilus. 


\subsection{Identification of flavonoids}

U.V. spectroscopy is one of the most descriptive and clearly attained forms of data and is very important in the study of flavonoids.

Flavonnoids exhibit two major absorption maximum with two distinctive bands at 240 - 285 $\mathrm{nm}$ (Band II) and at the range $300-400 \mathrm{~nm}$ (Band I). The absorption band II may be due to the Aring benzyl system, while band I is originated from the B-ring cinnamoyl system (Harborne et al., 1975; Haslam,1998 and Krueger et al., 2003). Data of U.V. Spectral analysis in methanol and by diagnostic reagents are recorded in Table (2), for further identification co-chromatography was carried out using authentic samples.

Complete controlled acid hydrolysis and ${ }^{1} \mathrm{H}$ NMR spectroscopy are shown in Table (3) and Fig. (1). Modern physical tools such as proton or nuclear magnetic resonance spectroscopy (PMR) or (NMR) proved to be valuable tools for the elucidation of the structure of flavonoidies and more complex flavonoid derivatives for measuring the magnetic moments of the hydrogen atoms which are attached to different groups in such flavonoid compounds. By these means the NMR spectra provide the number of hydrogen atoms in different situation (Harborne et al., 1975; Brown et al., 2001 and Hagerman, 2005).

\subsection{Antibacterial effect of flavonoid and phenolic compounds}

The study of antibacterial effect of diethyl ether, ethyl acetate, the aqueous solution of residual material and some of the isolated compounds are reported in Table (4).

The results show that the diethyl ether extract contained flavonoids i.e. kaempferol, quercetin and apigenin and had more inhibitory effect on bacteria Escherechia coli, Brodetella broshiseptica, Staphylococcus aureus, Sarcina lutea, Bacillus pumilus and Bacillus subtilus (Harborne and Baxter, 1993 and Lin et al., 1997). Whereas, ethyl acetate extract contained luteolin, and had a role of antibacterial. Taj and Nagarajan (1996) reported that luteolin is anti-mutagenic and had anti-inflammatory and antibacterial activities. Gallic and ellagic acids are phenolic compounds and have antimicrobial function (Kubo et al., 1993 and Chu et al., 2000).

From the above results it could be concluded that the extracted compounds (diethyl either and ethyl acetate extract) from red sorghum bran contained flavonoid (i.e. Escherechia coli, Brodetella broshiseptica, Staphylococcus aureus, Sarcina lutea Bacillus pumilus and Bacillus subtilus) and phenolic compounds that had antibacterial activity .
These compounds are currently gaining attention as antibacterial. More research is needed to clarify that the sorghum bran could be used as a wide source of biochemical diversity, colorants and for various industrial utilizations.

\section{REFERENCES}

A.P.H.A. (1971). American Public Health Association. Recommended Methods for the Microbiological Examination of Food. Amer.Public Health Assoc. Inc. New York.

Awika J.M. and Roony L.W. (2004). Sorghum phytochemicals and their potential aspects on human health.Phytochemistry.65:11991221.

Awika J.M.,Roony L.W.and Waniska R.D. (2004). Properties of 3-deoxyanthocyanins from .sorghum. J. Agric. Food. Chem. 52:4388-4394.

Bowles B L. and Jay J.M. (1993). The effect of phenylglyoxal on Clostridium sporogenes . Food microbial., 10:113-121.

Bowles B.L and Miller A.J. (1993). Antimicrobial properties of aromatic and aliphatic aldehydes .J. Food protect.,56:788-794

Brown D., Rashotte A., Murphy A., dormanly J., Tague B., Peer W. and Muday G. (2001). Flavonoids act as negative regulators of auxin transport in vivo in Arabidopsis. Plant Physiol. 126:524-535.

Chung T., Wei C., Huang Y. and Lin Y. (1998). Tannins and human health: A Review. Crit.Rev.Food Sci. Nutr.38:421-464.

Chu Y.H., Chang C.L. and Hsu H.F. (2000). Flavonoids content of several vegetables and their antioxidant activity. Jj. Sci. Food Agric.,80:561-566.

Dicko M., Gruppen H., Traore A., Van-Berkel W. and Voragen A. (2005). Evaluation of the effect of germination on control of phenolic compounds and antioxidant activities in sorghum varieties. J.Agric.Food Chem.. 53:2581-2588.

Dicko M., Gruppen H., Traore A., Voragen A. and Van-Barkel W. (2006). Phenolic compounds and related enzymes as determinants of sorghum for food use. Biotechnol.Mol.Biol.Rev.1:21-38.

Dillard C.J. and German J.B. (2000). Phytochemicals: hutraceuticals and human health.J.Sci. Food Agric.,80:1744-1756

Dykes L., Roony L., Waniska R. and Roony W. (2005). Phenolic compounds and antioxident activity of sorghum grains of varying genotypes.J.Agric.Food Chem. 53:6813-6818. 
F.A.O. (2005). FAOSTAT Agricultural database 2005.

Ferreira D. and Slade D. (2002).Oligomeric proanthocyanidins: naturally occurring $\mathrm{O}$ heterocycles. Nat. Prod. Rep. 19:517-541.

Food and Agriculture Organisation (F.A.O.) (2005). FAOSTAT Agricultural database 2005.

Geissman T.A. (1962). The Chemistry of Flavonoid Compounds. Pergamon Press, London, New York.

Hagerman A.E. (2005).Tannin Chemistry; Hagerman, A. E. Ed., Department of Chemistry and Biochemistry. Miami University Oxford, OH 45056 USA. Consulted on 10-09-2005.

Harborne J. and Baxter H. (1993). Phytochemical Dictionary:A Handbook of Bioactive Compounds from Plants, Taylor and Francis, London, UK.

Harborne J., Mabry T. and Mabry H. (1975). The Flavonoids. Chapman and Hall LTP, London.

Harris F.D. (1992). Regulation of antioxidant enzymes. FfASABJ., $6: 2675-2683$.

Haslam E. (1998). Practical Polyphenolics: from Structure to Molecular Recognition and Physiological Action Haslam,E. Ed, Cambridge Univ. Press. Cambridge. UK.

Jacobes M.B. and Gerstin M.J. (1960).’Handbook of Microbiology". D.Van Nostrand Company.Inc New York p.193-207.

Kahkonen M., Hopia A.,Vourela H., Rauha J., Pihlaga K, Kujala T. and Heinonen M. (1999). Antioxidant activity of plant extracts containing phenolic compounds. J. Agric. Food Chem., 47:3954-3962.

Kinsella J., Frankel E., German B. and Kanner J. (1993). Possible meachanisms for protective role of antioxidants in wine and plant foods. Food Technol.47: 85-89.

Knekt P., Kumpulainen J., Jarvinen R., Rissanen H., Heliovaara M., Rreunanen A., Hokulinen T. and Aroma A. (2002). Flavonoid intake and risk of chronic diseases. Am. J. Clin. Nutr., 76: 560-568.

Krings U. and Berger R. (2001) Antioxidant activity of some roasted foods. Food Chem., 72: 223-229.

Krueger C.G, Vestling M.A. and Reed J.D. (2003).Matrix-assisted laser desorption/ionization time-of-flight mass spedrometry of heteropolyflavan-30ols and glucosylated heteropolyflavansin sorghum (Sorghum bicolor L ) Moench. J. Agric. Food. Chem. 51: 538-543.
Kubo I., Murio H. and Himegima M. (1993). Antibacterial activity against Streptococcus mutans of meta flavor components. J. Agric. Food. Chem.,41: 107-111.

Lacobucci G.A. and Sweeny J.G. (1983). The chemistry of anthocyanins,.anthocyanidins and related flavylium salts. Tetrahedron, 39:3005-3015.

Leuschner R. and Ielsch V. (2003). Antimicrobial effect of garlic, clove and red hot chilli on Listeria monocytogenes in broth model system and soft cheese. Int. J. Food Sci. Nutr. 54: 127-133.

Lin J.K., Chen Y.C., Huang Y.T. and Lin- Shiau S.Y. (1997). Supression of protein Kinase Cand nuclear oncognene expression as possible molecular mechanisms of cancer chemoprevention by apigenin and cumarin J. Call. Biochem.Suppl. 28 (29): 39-48.

Mabry T.J., Markham K.R. and Thomas M.B. (1970). The Systematic Identification of Flavonoids , Springer Verlag, New York, Heidelberg, Berlin.

Markham K.R. and Mabry T.J. (1968). The identification of twenty three 5-deoxy and ten 5-hydroxy flavonoid from Baptisa leconti. Phytochem. 7, 1197.

Negi P.S. and Jayaprakasha G.K. (2003). Antioxidant and antimicrobial activities of Punica granatum peel extracts. J. Food Sci., 68 (4); 1473 - 1477.

Rice-Evans C., Miller J., Bolwell P., Bramelly P. and Pridham L. (1995). The relative antioxidant activities of plant derived polyphenolic flavonoids. Free Rad. Res., 22:375-383.

Sandak R.N. and El-Hadidy E.M. (2004). Utilization of natural antioxidants and their effects on human health. Egypt, J. Agric. Res., 5 (1): 47-61.

Seshadry T.R. (1962). The Chemistry of Flavonoid Compounds. Oxford, Pergamon Press, p159.

Taj,S. and Nagarajan,B. (1996). Inhibition by quercetin and luteolin of chromosomal alteration induced by salted, deep-fried fish and mutton in rats. Mutat. Res.369: 1-(2) 97-106.

Waniska R.D. (2000). Technical and institutional Options for Sorghum Grain Mold Management: Proceeding of an International Consultation.Chandrasheker,A,Bandyopadt yay, R, and Hall,A.J.(Eds) ICRISAT, Patancheru, India. P72-106.

Yen G.C. and Due P.D. (1993). Antioxidative properties of methanolic extracts from peanut hulls. J. AOCS, 70 (4) 383-386. 


$$
\begin{aligned}
& \text { دراسات على بعض المركبات الفينولية والفلافونيدية لقشور السورجم الاحمر } \\
& \text { ونشاطها المضاد للبكتيريا } \\
& \text { سمية محمد مرسى -*مى سامى حلبى - رأفت نجيب سندق }
\end{aligned}
$$

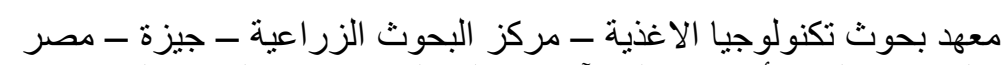

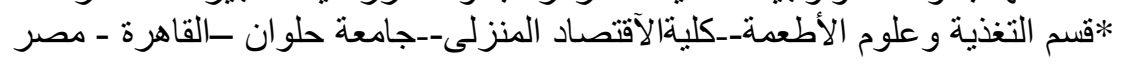

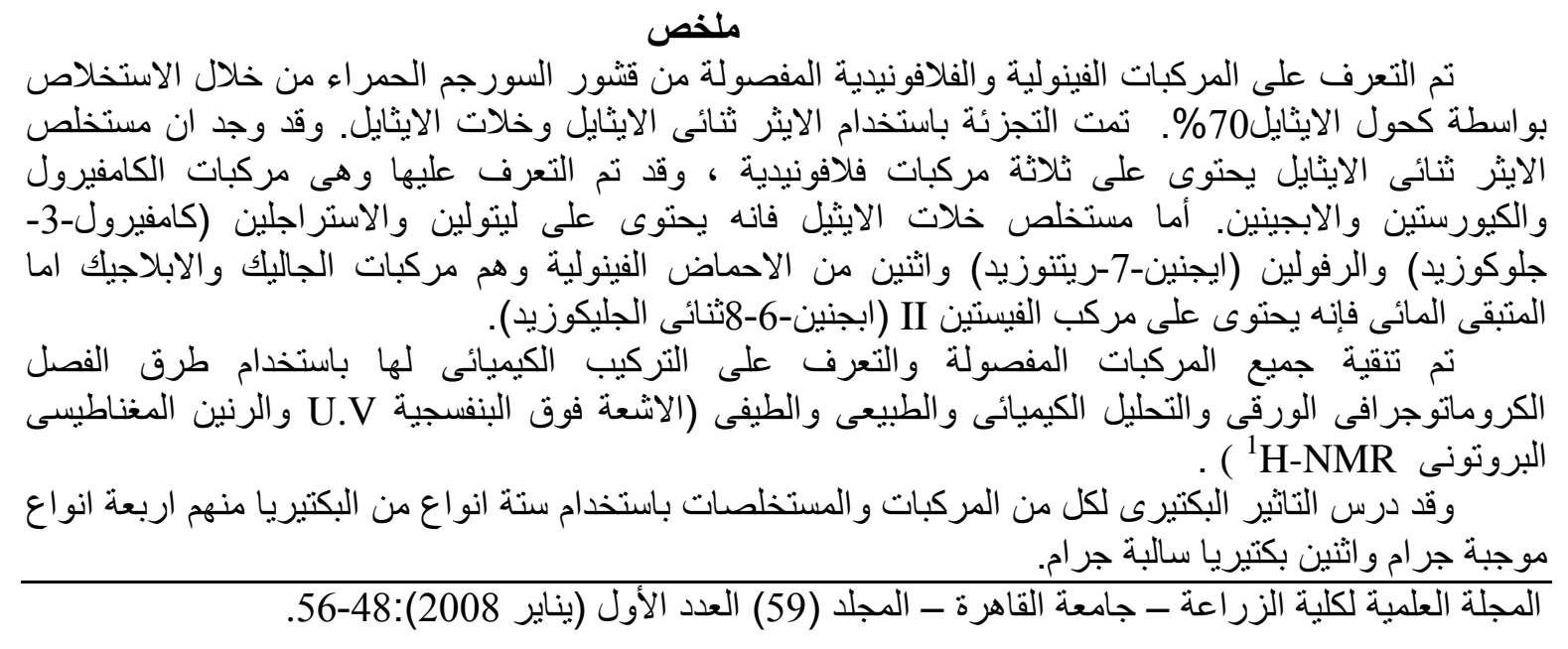

